\title{
OMPARATIVE STUDY OF ACADEMIC SUPERVISION, ACHIEVEMENT MOTIVATION AND TEACHER PERFORMANCE AT SOUTHEAST MALUKU REGENCY
}

\author{
Patrisius Rahabav*, and Sumarny Rumfot \\ Postgraduate Educational Management Study Program \\ Pattimura University, Ambon \\ *e-mail: prahabav@fkip.unpatti.ac.id
}

\begin{abstract}
The purpose of this study was to test the significance of differences in academic supervision by principals on achievement motivation and teacher performance in elementary, junior high and senior high school / vocational high schools in Southeast Maluku Regency. The study population was 136 schools. Teacher samples were taken using a purposive sample technique based on criteria that had 10 years of teaching experience and were certified. The total sample of teachers was 160 people with the following details: elementary school: 52 teachers; Junior High School: 52 teachers; Senior High School: 52 teachers and Vocational High School: 4 teachers. In addition, 6 teachers and 3 principals became participants to be interviewed. Those interviewed did not include the number of samples. This research approach uses mixed methods. Data collection techniques used were questionnaires, interview guides and study documentation. Data analysis techniques used were descriptive statistics, ANOVA 1 lane and qualitative analysis. The results showed that there were no significant differences in the mean of academic supervision and teacher achievement motivation in the three sample groups and there were significant differences in teacher performance in the three samples. Based on the results of the qualitative analysis it was found that academic supervision was carried out without a program, the frequency and intensity of academic supervision conducted by the principal was very less. Supervision of school principals without using standard instruments, and the absence of the results of the analysis of supervision implementation Supervisors still use the bureaucratic-autocratic approach and are not participatory. Teacher achievement motivation is still very dominant triggered by welfare factors. The teacher has shown discipline, not delayed work. However, teachers have not displayed creative, innovative attitudes, independence in work, adaptability and have not reached high performance standards. The results of qualitative analysis of teacher performance variables, it was found that most teachers do not prepare their own lesson plans but copy and paste lesson plans from network sources or other colleagues; teacher copy paste Basic Competencies and indicators exactly as contained in the Minister of National Education Regulation. The teacher does not understand the preparation of HOTS (Higher Order Thinking Skill) questions and also has not been able to compile an assessment rubric. The lesson plans prepared by the teacher are only prerequisites for teaching; so it is only to fulfill formal-administrative demands and not be seen in class performance.
\end{abstract}

Keywords: Academic supervision, achievement motivation and performance

\section{Introduction}

Since 2012, the test results of Maluku teacher competency still place on $32^{\text {nd }}$ ranked of 34 provinces in Indonesia, (https://www.beritasatu.com / national / 334613 / h.accessed March 13, 2019). The competency test results are a prerequisite for high and low teacher performance. Facing this problem, the government, in this case, the Ministry of Education and Culture, has made various breakthrough efforts both through improving qualifications and increasing teacher competence (training, seminars, workshops, teacher assistance with professional associations) and certification. However, the government's ability is very limited. In this context another method is needed. One of them is through 
supervision. Supervision is professional assistance provided by the principal as a supervisor.

According to Segun (2004), supervision stimulates professional growth and teacher development, revisions to educational goals, selection of learning materials, teaching methods, and evaluation of learning (Bessong and Ojong, 2009). The supervision of modern education, as stated by Bailey (2006) is a technical process that seeks to improve teaching and learning through continuous care, guidance and simulations not only for teachers but also for everyone who has an impact on the educational context.

In line with the above constellation, Ngala (1997) suggests that the principal supervise the teacher to ensure that: learning is planned early; structured lessons so interesting; revision of previous knowledge and use of variations of sound by the teacher and a summary of the main points at the end of learning; The teacher uses teaching aids correctly; The teacher has a good relationship with students and the teacher consistently applies the curriculum. Okumbe (1999) states that supervision is an administrative strategy that aims to stimulate teachers to increase effectiveness and greater pedagogical productivity. Supervision functions to stimulate teachers to improve their professional abilities.

Supervision consists of 2 types are managerial supervision and academic supervision. Academic supervision is professional guidance conducted by supervisors to improve teacher performance in learning activities. Rahabav's study (2016) found that most principals did not yet have prerequisite competencies as a principals to carry out academic supervision and managerial supervision. This condition according to (Rahabav, 2014), is a logical consequence of the appointment of the principal who ignores the competency approach and the merit system. Most school principals are not prepared with initial training as prospective principals.

The Ministry of National Education (2011: 85) adds that most principals in Indonesia are not equipped with sufficient training or knowledge of modern school management. Most principals are appointed based on evaluations or recommendations from package four education officials, not through a formal selection process based on skills assessment. The training provided regarding the duties of the principal was very minimal. The competency development program for school principals as school leaders is sometimes limited to a brief presentation of policy documents issued by regional offices. As a result, only a few school principals carry out proactive supervision and function as guides to improve teacher performance.

Beside academic supervision, achievement motivation variables also affect teacher performance. Achievement motivation is a very strong impetus in an individual to achieve superior standards of achievement (Rahabav: 2015). In that context, if supervision is carried out properly, it will spur teachers to increase their motivation for achievement and ultimately have an impact on improving teacher performance.

Rahabav, (2016) reported that the frequency and intensity of academic supervision was still lacking, the target of observation was still general and tended to focus on teaching administration or Learning Implementation Plan and had not touched the teacher's performance in learning. On the other hand, the teacher's achievement motivation has not shown encouraging developments. Conditions such as those mentioned above if not addressed will have an impact on low teacher performance as well. This research was conducted with the aim of testing the significance level of differences in academic supervision.

School effectiveness is highly dependent on the principal's ability to supervise teachers, clarify learning goals and work collaboratively to improve the quality of the learning process (Blasé, Blasé \& Philips, 2010; Smylie, 2010). Academic supervision becomes one of the important aspects in education management. Academic supervision is defined as a process of improvement in the learning process that is carried out cooperatively and democratically to achieve an effective education system (Oyewole and Ehinola, 2014). Academic supervision is seen as a collaborative effort involving a series of structured 
activities with the aim of improving the teaching and learning process whose results can be monitored in student learning in class (Aguba, 2009; Archibong, 2013).

Academic supervision is not designed to find fault even more with punishment, but rather sees teachers as colleagues and works together to improve the quality of learning in schools. Researchers and academic supervision experts have identified various models that teachers like and used by supervisors in their supervision practice.

In choosing the supervision model, Glickman (2002) states that it is very important for supervisors to consider the level of development, the experience of the teacher in teaching practice, and the context in which the teacher works. Some of the models of academic supervision are coeval supervision, clinical supervision and development supervision. Sergiovanni and Starratt (2007) explain that in coeval supervision, teachers work together with their coeval friends to develop their professional abilities. Therefore the teacher is involved in the supervision task by visiting each other's classes to learn, provide assistance, criticize each other's learning planning, examine together the work of students, and assess the quality of teaching and learning received by students.

Glathorne (2000) further explained that supervisors with different approaches or supervision styles gave teachers access to make choices about the type of supervision method they wanted to adopt. The model chosen, assumes that all teachers must involve themselves in evaluation, staff development and supervision activities to improve their abilities regardless of their experience and competence. It can be concluded from the description that in supervision is not a type, a different supervision model, but the use of a supervision approach that considers the condition of the teacher. Therefore Glathorne (2000) argues that the clinical supervision model, is collaborative, and is directed at teacher development and growth.

Research (James and Balasandran, 2012; Vijayaamalar and Suhaida, 2013; Wan Shafira, 2011) found that supervision influences changes in teacher attitudes. However, this finding is not supported by the results of research by Meor Ibrahim and Norziana (2008) who reported that autocratic or bureaucratic supervision did not affect teacher attitudes because there was no collaboration, discussion and feedback between supervisors and supervised teachers. Shukri (2004) argues that the teacher's negative attitude towards supervision is because teachers feel threatened during an annual performance appraisal. For them supervision is a summative assessment and is not beneficial for improving the quality of their teaching. Teachers do not feel the guidance of supervisors in solving problems faced by them in teaching.

In addition, (Muhamad Sani, 2002) found that teachers had doubts about the supervision conducted by principals because they doubted the competency of principals related to subjects taught by teachers. That doubt, according to (Mardhiah and Rabiatul, 2016) arises because there are no special courses related to supervision given to the principal. Chan and Gurnam, (in Rozalina Khalid, et, all; 2019) found that the principal did not carry out professional responsibilities and was not actively involved in the supervision process. Well-done academic supervision encourages teachers to improve achievement motivation and performance.

Teacher motivation includes strength both inside and outside the individual. According to Hicks (2011) internal motivation consists of the needs, desires and intentions that exist in the teacher including his thoughts which ultimately trigger positive behavior changes towards increased learning. Teacher motivation implies that teachers need physical satisfaction. Elements of physical satisfaction include: food, water, shelter etc. In addition, teachers should be able to meet needs such as insurance, medical benefits, retirement benefits, etc. In that context school management must be more concerned with providing meaningful and challenging work, encouraging responsibility, recognizing performance, creating growth opportunities and encouraging teachers to be independent in acting. In this research, the writer will study achievement motivation. Achievement motivation according to Hilgard (1983) is a social motive to do something valuable or important well and 
perfectly to meet the standards of excellence of what someone does. What a person does is basically to get recognition from others for the achievements he has achieved. McClelland (1975) uses the term need for achievement (N-Ach) for the need for achievement that is as an impetus for someone to succeed in competing with a standard of excellence. A person who has achievement motivation will look for situations where they can reach personal responsibility to find a solution. The characteristics of someone who has high achievement motivation is expressed by Mc. Clelland is 1). Have a desire to compete in a healthy manner with himself or with others. 2). Have a desire to work well. 3). Thinking realistically, knowing his abilities and weaknesses. 4). Have personal responsibilities 5). Able to make breakthroughs in thinking 6). Thinking strategically in the long run 7). Always use feedback for improvement. Some traits of someone who has high achievement motivation include (1) having high responsibilities, (2) having a work program based on realistic plans and goals and striving to make it happen, (3) having the ability to take decision and dare to take risks, (4) doing meaningful work and completing it with satisfying results and (5) having the ability to be prominent in mastering a particular field (Degeng, 1991).

Atkinson (in Rahabav, 2015) said that achievement motivation is called high if the desire for success is greater than fear of failure. Atkinson further stated that someone who has high achievement motivation has the following characteristics: 1) has a high responsibility for his task, 2) sets challenging, difficult and realistic goals, 3) has hope of success, 4) makes a great effort to achieve success, 5) never think of failure, and 6) try to get the best results. According to Rahabav (2014: 159) someone who has high achievement motives is characterized by: 1) respecting time (disciplane), 2) persevering, 3) staying under pressure, 4) being creative, 5) being innovative, 6) always looking for feedback to work, 7) not delaying work, 8) choosing challenging work, 9) having independence at work, and 10) achieving high performance standards.

Good achievement motivation will trigger teacher performance. Performance is the actual achievement achieved by a person or organization through high competence and motivation so that outputs and outcomes are achieved in accordance with the target time, goals and standards set by an organization (Rahabav, 2014). Performance is basically what employees do or don't do. Employee performance affects how much employee contributions to the organization include the quantity of outputs, the quality of outputs, the period of outputs, the presence at work and the cooperative attitude. Lawder \& Poter (in Patris Rahabav 2014) argues that performance is the "successful role" that a person gets from his actions. Ivancevich (1997) states that someone who has the ability with the business will determine one's performance. Further explained that the business will be influenced by the strength of the motives that exist in the individual. Likewise with environmental factors. According to Ivancevich, environmental factors also influence a person's performance. The model proposed by Ivancevich can be seen in Figure 1 . 


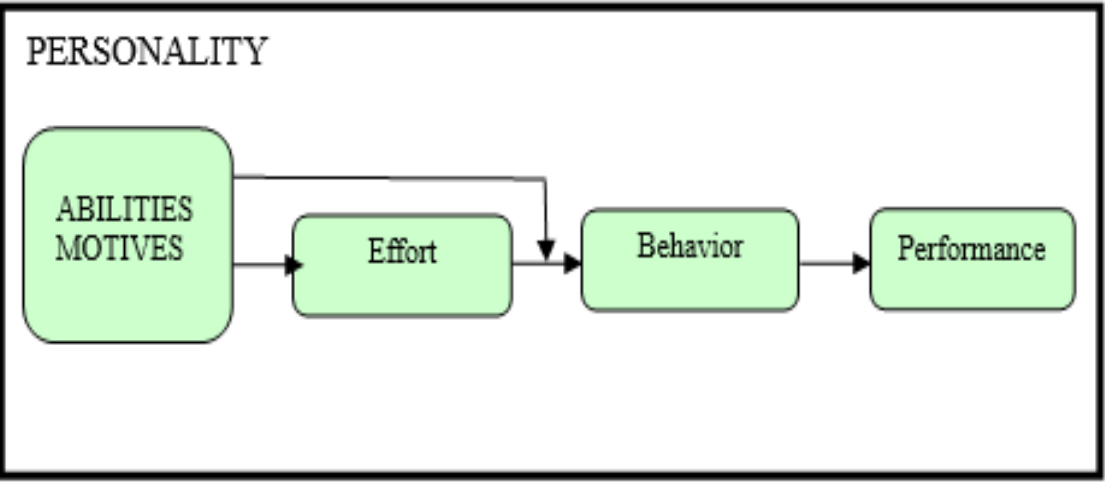

\section{Gambar 1. Determinant of individual behavior and performance Sumber: Ivancevich, etal,(1977:49) Organizationa/ Behavior and Performance, Santa Monica California.}

The same thing was stated by Heider (in Anderson \& Butzin, 1974) who formulated work performance as a result of the interaction between motivation and ability (basic ability). Thus, people who have high motivation but have low ability produce low performance. Similarly, people who have high ability but low motivation will produce low performance as well. Formula Heider as shown in Figure 2.

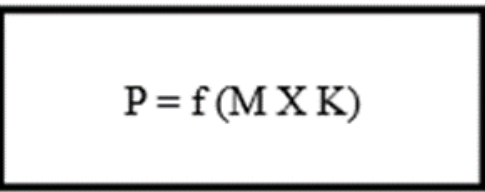

Gambar: 2: Formula Pembentuk Kinerja menurut Heider

$$
\begin{aligned}
& \text { Keterangan: } \\
& \mathrm{P}=\text { Performance } \\
& \mathrm{M}=\text { Motivation } \\
& \mathrm{A}=\text { Ability }
\end{aligned}
$$

Based on that, Vroom (in Rahabav, 2014) suggested that employees to be trained must be highly motivated, while employees who need to be motivated are those who are highly capable. In other words, if one's work performance (work performance) is low, then this is the result of low motivation or poor ability or the results of both components (motivation) and (ability) are low. Robbins, (1996) complements the concept by adding an opportunity variable so that performance is an interactive function between ability (A) motivation (M) and opportunity $(\mathrm{O})$ with the formula: Performance $=\mathrm{f}(\mathrm{A} \times \mathrm{M} \times \mathrm{O})$.

This means that performance is a function of ability, motivation and opportunity. Schematically, Robbins's view is visualized in the figure below 


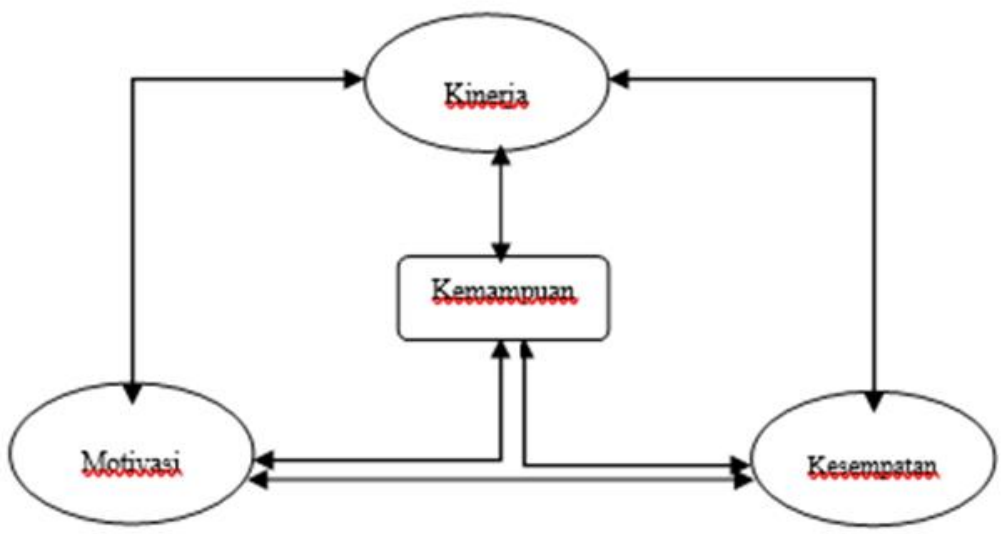

Figure3: Forming Formulas of Performance according to Robbins (1996) Source: Rahabav (2014).

According to Schuler and Dowling (in Kramar, Mcgraw \& Schuler, 1997: 371) performance can be measured by (1) the quantity of work, (2) the quality of work. (3) cooperation, (4) knowledge of work, (5) work independence, (6) attendance and promptness, (7) knowledge of organizational policies and objectives, (8) initiative and the delivery of healthy ideas, (9) ability supervision and technical.

The performance measures according to T.R. Mitchell (1989) in Patris Rahabav (2014) can be seen from four things: 1). Quality of work - the quality of work, 2).Promptness - the timelaness of completing work, 3). Initiative - initiative in completing work, 4). Capability - the ability to get work done. 5). Comunication - the ability to foster cooperation with other parties.

Furthermore according to Rahabav (2014) teacher performance can be measured from 10 (ten) dimensions as follows: 1) the number of products produced; 2) the quality of the product produced; 3 ) the ability to teach and complete the tasks entrusted; 4) creativity, 5) work independence; 6) adaptability; 7) cooperation; 8) commitment to the task; 9) pride in the profession; 10) customer satisfaction for the product produced.

\section{a. Number of products produced}

High or low performance of teachers is measured by how many products are produced. The number of products produced by teachers is defined as how many products and services teachers achieve in a certain period of time. Products produced by teachers are measured by indicators: Syllabus, Learning Implementation Plan, teaching aids, works of art / appropriate technology, research proposals and reports, scientific publications and teaching materials (modules, books, practicum guides and so on). Services can be measured by indicators: home visits, counseling services, consultations, art advisers, youth red cross, scientific writing competitions, speech competitions, scouts, remedial teaching, and other students' self-development.

\section{b. The quality of the product produced}

The quality of products produced is defined as service products produced by teachers who have high quality and competitiveness, according to the standards or tastes of consumers. With regard to product or service quality, the standard is very relative. However, in the end the quality of the product or service is determined by the market or consumers. School consumers who use teachers' products or services are students, parents and education stakeholders. So, the high and low of teachers' products or services will be determined by their reaction. The quality of the product or service of the teacher is more specifically related to the main task of the teacher as an educator and teacher. 
In that context product quality can be measured by indicators: physical appearance of the product such as size, model, neatness, artistic side and so on. Whereas service quality is measured by indicators: frequency and intensity of services, seriousness, disciplane, and patience in providing services.

\section{c. Ability to teach and complete the tasks entrusted}

Teacher's work is professional work. Therefore it can only be done by people who have been specifically trained for it. The ability to teach is one of the parameters measuring the extent of the teacher's professional ability.

The ability to teach is defined as the actual ability shown by the teacher in organizing classes that stimulate students to learn. The ability to teach in detail can be measured by indicators: the ability to open learning activities with good apperception, the ability to set classroom, the ability to use variations in teaching, the ability to use learning methods and resources, the ability to explain, the ability to motivate or reinforce, the ability to ask, the ability to open and closing lessons, the ability to conduct individual coaching, and the ability to evaluate learning.

Whereas the ability to complete an entrusted task is defined as the ability to respond and carry out the entrusted task quickly and accurately. The ability to complete a task entrusted to the teacher professionally, measured by indicators: efficiency, effectiveness, productivity and accountability.

\section{d. Creativity}

Creativity is defined as the ability to think and engineer ideas and create new highquality products or works of art. Creativity according to Munandar, (1977) is the ability to reflect fluency, flexibility, and originality in thinking and the ability to elaborate (develop, enrich, detail) an idea. Creativity is the manifestation of the individual who functions fully in his self-realization.

In that context the teacher cannot simply accept an idea or concept but continue to try to make modifications, elaboration and enrichment so as to produce something new ideas or concepts. In carrying out the task, a creative teacher will always try to renew his performance by looking for various innovations and breakthroughs so that there is always renewal in the teacher concerned.

Creative teachers are teachers who are not silent but are always dynamic; looking for various ideas, creating various products, especially the latest learning technology so that it enhances its performance in the learning process. Teacher creativity is measured by indicators: the ability to think convergent, solve problems quickly, have high imagination and creativity, and be tempted to always try new things.

\section{e. Independence of work}

Work independence is defined as work autonomy which reflects the competence and responsibility of the teacher to carry out the tasks entrusted without the control and intervention of the principal or others. Work independence is one of the characteristics of teacher performance. Experience proves that some teachers work when instructed. In working, some teachers cannot work alone. They only show good performance if they are guided by the principal or other teacher colleagues. Work independence comes first from the intellectual abilities obtained by the teacher from education, training and experience as a teacher.

Intellectual ability alone is not enough. Work independence, only complete when added to the awareness to work seriously. In detail work independence is measured by 
indicators: self-confidence, intellectual independence, resistance in facing work demands, ability to solve problems and initiatives in carrying out work without waiting for command, or supervision.

\section{f. Adaptability}

Teachers are now faced with the increasingly massive challenges of globalization. Facing these challenges, adaptability is needed. Adaptability is defined as the ability of teachers to adapt quickly to the challenges of changing science, technology and art so that they do not drift away, but always survive. Specifically teachers who have high adaptability are measured by indicators: thirst for knowledge so that motivates them to read, discuss, share, research, examine new things, be able to adjust to changes in curriculum, methods or policies, calm in the face of new things, respond positively to creative ideas.

\section{g. Cooperation}

Cooperation is defined as the ability of related teachers to get support from all parties to their professional assignments. Collaboration can be measured by indicators: the ability of the teacher to establish communication with colleagues; with students; with parents of students; ability to network with business and industry; the ability to use this collaboration and support to improve the quality of the learning process and advance school programs.

\section{h. Commitment to work}

The work of teaching and educating is strenuous but noble. This narration emphasizes that the work of teaching and educating, has a deeper meaning than just a job that is lived as a routine activity. Commitment to work is defined as the teacher's physical and emotional involvement. A total surrender to work without taking into account matters relating to incentives or welfare. Commitment to work is measured by indicators: discipline, responsibility, lack of complaints, accepting assignments with pleasure, empathy, and selfless service.

\section{i. Pride in the profession}

A job that is lived as a profession, is different from ordinary work. A professional will have different perceptions from ordinary workers. The teacher is a professional worker. Thus, they will have a different view from someone who only makes teaching and teaching work a part-time activity. Pride in the profession is defined as the psychological reaction of the teacher to the profession that is carried as a noble and respected profession that gives teachers confidence.

Pride in the profession as one of the characteristics of teacher performance in detail is measured by indicators: have a good perception of the teaching profession, make the teaching profession as the main source of life, work full time for the task of educating and teaching, upholding professional ethics by maintaining honor and dignity teacher.

\section{j. Customer satisfaction for the products produced}

Teacher performance is ultimately determined by the customer. The customer determines all the products or services provided by the teacher. Like a practicing doctor who sells services in the form of health examination and consultation services, we can see that there are doctors who are lonely patients and some are not able to serve patients. Likewise with the teacher. Customer satisfaction is defined as the recognition and appreciation of customers for products or professional services provided by the teacher.

In detail customer satisfaction with products or services produced by teachers is measured by indicators: recognition of teacher competence, positive responses to professional practices by teachers, increased appreciation and respect for teacher dignity, increased customer confidence and demand for products or services provided (tutoring, 
courses, lectures, consultations, etc.), lack of complaints about the products or professional services provided by the teacher.

\section{Research Methods}

This research approach is mixed methods. The model used, is quantitative facilitating qualitative. There are three independent variables studied are: First, supervision with indicators: 1) supervisor competency; 2) supervision programs are planned together; 3 ) the use of varied supervision techniques; 4) giving feedback according to the teacher's problem; 5) supervision is carried out in a participatory manner; 6) teacher support and commitment to improve themselves continuously; 7) continuity of guidance and assistance; 8) increasing teacher competency in the learning process; 9) increasing the absorption of students; 10) continuous supervision evaluation. Second, achievement motivation with indicators: 1) respecting time (discipline), 2) persevering, 3) staying under pressure, 4) creative, 5) innovative, 6) always looking for feedback on work, 7) not delaying work, 8) choose a challenging job, 9) have independence in working, and 10) achieve high performance standards. Third, Teacher performance with indicators: 1) number of products produced; 2) the quality of the product produced; 3) ability to teach and complete assignments; 4) creativity, 5) work independence; 6) adaptability; 7) cooperation; 8) commitment to the task; 9) pride in the profession; 10) customer satisfaction for the product produced.

The study population was all teachers who taught at elementary, junior high, high school and vocational schools in Southeast Maluku Regency. The total number of schools is 207 with details: elementary, 131; Junior High School 45; Senior High school, 24 and 7 Vocational School. Sampling is done in stages. In the first stage, a purposive sample technique was used to determine the number of schools according to levels; with accredited criteria. With these criteria, the number of schools that have been accredited is 205 schools. The second stage, after getting the number of schools, the number of schools is determined. The technique used is simple random sampling. Determination of the number of samples using the formula proposed by Slovin in Rahabav (2012), as follows:

Information :

$$
n=\frac{N}{N \cdot d^{2}+1}
$$

$\mathrm{n}=$ Number of Samples

$\mathrm{N}=$ Number of known population

$\mathrm{d}=$ The degree of error

Based on the formula above, the sample size will be calculated using an error rate of $5 \%$ as follows:

$$
\mathrm{N}=\frac{N}{N \cdot d^{2}}+\frac{205}{(205) \cdot 0.05^{2}+1}=\frac{205}{1,51}=136
$$

The third stage is the determination of teacher samples. The sample technique used is purposive sampling. For this purpose, the criteria used are: S1 qualification, certified and work experience of at least 10 years. Based on these criteria, a sample of teachers obtained from 136 schools totaling 160 teachers with details of 52 elementary school teachers; 52 junior high school teachers; 52 senior high school teachers and 4 vocational school teachers. Thus, the total sample of teachers who will be respondents are 160 respondents. 
In the fourth stage, 9 informants were selected to be interviewed with details of 3 principals and 6 teachers. Those interviewed were not included in the sample of teachers who were determined as the main respondents in this study.

Data collection techniques used in this study was non-test techniques in the form of questionnaires and interview guidelines. The questionnaire was compiled based on the Likert scale. Before the research is conducted, first test the validity and reliability of the items. The guideline used to determine whether the items tested try to qualify or not, namely the correlation coefficient between the score of the item and the total score is positive and the correlation of items with the score (rhit) $=0.30$ after deducting the correction factor (Guilford and Frutcher 1982 in Rahabav 2012). If the price of $r$ count is greater than or equal to 0.30 the instrument is declared valid or valid, meaning that the instrument can really measure the parameters to be measured. Conversely, if the $r$ count is less than 0.30 , then the items in the instrument are declared invalid or fall, so they must be dropped or discarded. The results of the validity test of academic supervision variables, totaling 54 items; job satisfaction as many as 30 items and teacher performance as many as 72 items. The reliability test of the principal's supervision item is obtained by Cronbach's Alpha of 0.94; Cronbach's Alpha job satisfaction by 0.85 and teacher performance obtained by Cronbach's Alpha by 0.94. Thus the three instruments are declared reliable.

The data analysis technique used is statistical analysis (descriptive and inferential) and qualitative analysis techniques. Descriptive statistical analysis techniques, used to calculate the mean, mode, standard deviation, minimum, maximum. Then the results are continued by placing the ranking low to high. Inferential analysis is used to analyze differences in teacher perceptions of the variables studied. For this purpose, ANOVA 1 lane will be used. Whereas, qualitative analysis is used to give further meaning from the results of statistical analyses both descriptive and inferential.

\section{Results and Discussion}

The results of data analysis using descriptive statistics on academic supervision variables, obtained a minimum score of 98 , a maximum score of 132, a mean of 114.11, a standard deviation of 7.520. The results of the analysis of mean differences, mean empirical scores are lower when compared to the hypothetical mean score $(210<270)$. The results of the analysis of the perception of 160 respondents $=28236: 43,200=65 \%$. Based on the continuum lane, the value 39081 is between medium to high intervals. Thus, it was concluded that respondents' perceptions of the supervision of school principals were in the moderate / good category. The results of this study are in lane with the study of Kweku Esia-Donkoh and Eric Ofosu-Dwamena (2014) in their study found that teachers in elementary schools in Winneba, Ghana, gave a positive perception that supervision was able to develop their professional abilities. Supervision updates the teacher's experience in curriculum development, learning methods and teaching materials, classroom management, student understanding and assessment techniques. The study also concluded that there were no significant differences in the perceptions of male and female elementary school teachers in Winneba, Ghana, in terms of developing teacher experience, classroom management, understanding students' characteristics, teaching materials, and assessment techniques. However, there are significant differences in the perceptions of male and female elementary school teachers in Winneba, Ghana, in terms of curriculum, learning methods and teaching materials.

Based on the results of the qualitative analysis it was found that supervision was carried out by the principal; not programmed, the frequency and intensity of academic supervision conducted by the principal is very less. Supervision of the principal has not used standard instruments, not analyzed. Principals also rarely use supervision books and do not make notes of findings and feedback regularly, supervision is not participatory and 
feedback tends to still be instructive. The empirical data shows how supervision for school principals has not been considered as essential. These conditions increasingly emphasize that supervision has not been handled professionally and has not been used as one solution to improve the quality of learning. This condition is very likely to occur because the recruitment of principals has not been carried out according to standards; lack of education and training or capacity building for prospective principals and principals. Thus, in practice, supervision by school principals is very bureaucratic and autocratic; supervision is not participatory. The supervisor still positions the teacher not as a partner but as a guilty person. Principals reduce their role as supervisors who should provide professional assistance so that teachers grow in office to give instructions; the supervisor does not foster the teacher, but gives direction. Supervision of the principal as mentioned makes the teacher in a condition that is not conducive and tends to show a mock attitude, even avoid supervision.

The results of this study are in lane with the results of several studies by Meor Ibrahim and Norziana (2008) who reported that autocratic or bureaucratic supervision did not affect teacher attitudes because there was no collaboration, discussion and feedback between supervisors and supervised teachers. Shukri (2004) argues that the teacher's negative attitude towards supervision is because teachers feel threatened during an annual performance appraisal. For them supervision is a summative assessment and is not beneficial for improving the quality of their teaching. Teachers do not feel the guidance of supervisors in solving problems faced by them in teaching. In addition, (Muhamad Sani, 2002) found that teachers had doubts about the supervision conducted by principals because they doubted the competency of principals related to subjects taught by teachers. That doubt, according to (Mardhiah and Rabiatul, 2016) arises because there are no special courses related to supervision given to the school principal. Chan and Gurnam, (in Rozalina Khalid, et, all; 2019) found that the principal did not carry out professional responsibilities and was not actively involved in the supervision process. In addition, a study by Hismanoglu and Hismanoglu (2010) with English teacher respondents in North Cyprus revealed that teachers showed a positive attitude towards supervision because it helped develop professional abilities, helping teachers to learn new trends in teaching. However, this study also found that lack of time and adequate financial resources were seen as two main obstacles to teacher professional development. The study also revealed the experience of teachers that supervisors in carrying out supervision were more trying to find mistakes in the classroom than involving them in discussions to overcome their challenges and concerns.

Burant (2009) in the study of learning supervision found that there was a significant relationship between instructional guidance and teacher professional development (Tesfaw and Hofman, 2012). Helmreich \& Spence (1978) examined achievement motivation with four parameters, namely satisfaction of needs, work orientation, competition, and personal indifference. 1. Fulfillment of needs: an individual prefers to a job that is challenging, demands an intellectual level and is oriented towards high thinking; Individuals like to play leadership roles in groups and are able to complete the tasks entrusted. 2. Work orientation: an individual takes a proactive attitude towards work and loves what he does. He gained satisfaction from work and pursued self-realization and growth. 3. Competition: an individual has high hopes to win and has a desire to win over others. 4. Personal indifference: an individual does not consider success or performance to be rejected by others. In other words, there is no fear of success. Helmreich \& Spence (1978), found that the interaction of three parameters, namely satisfaction of needs, work orientation, competition contributed positively to individual performance. This is in lane with studies (Spence \& Helmreich, 1983).

The results of data analysis using descriptive statistics on the principal's supervision variables, obtained a minimum score of 207, a maximum score of 299, a mean of 244.26, a standard deviation of 13.732. The results of the analysis of mean differences, the 
empirical mean of achievement motivation variables are lower when compared to the hypothetical mean score $(299<360)$. The results of the analysis of the perception of 160 respondents $=39081: 57600=68 \%$. Based on the continuum lane, the value 39081 is between medium to high intervals. Thus, it was concluded that respondents' perceptions of achievement motivation were in the moderate / quite good category. Furthermore, based on the results of the qualitative analysis it was found that teacher achievement motivation was still very dominant triggered by welfare factors. The teacher has displayed discipline, not delayed work. However, teachers have not displayed creative, innovative attitudes, independence in work, adaptability and achieving high performance standards.

The results of this study provide evidence that the obsession of teachers is not motivated by a call to serve but motivation to become a teacher because they want to become civil servants. So, incentive salaries become very dominant in all teachers' work. Idealism has vanished with very pragmatic interests. Such teachers, categorized as ordinary teachers who will work routinely, are monotonous, not curative, and not innovative and complain a lot. The results are in lane with Maslow's hierarchical theory of needs (in Noosheen Nawaz and Hina Yasin, 2015) that the first and foremost needs of every employee are physical needs and these physical needs can only be met by money. So, at the beginning of a career, only money can motivate employees in every industry. A comfortable life attracts more employees than the polite nature of the employer (Krishnan, 2003). Some researchers have concluded that the most important reason for demotivating employees is low salaries. According to Nbina (2010), middle school teachers lose motivation because of low salaries and poor facilities. Worker productivity can be increased from 25\% to 85-90\%, when they are motivated (Hersey \& Blanchard, 1988). From various factors salary is $1^{\text {st }}$ ranks. This means that the motivational power of salary is greater than other motivational factors for Bahawalpur private high school teachers. This is because salaries that are not paid on time result in teachers not being able to meet their needs. In addition to other factors: comfortable environment, positive student behavior, separate staff rooms for male and female teachers, especially veiled women, performance appraisals. Teachers can also lose motivation if strict supervision is carried out by school administrators. According to Dörnyei (2001) the following factors influence teacher motivation: school climate, existing school norms, class size, school resources and facilities, general expectations regarding student potential, leadership and decision making structures and autonomy. Results of data analysis using descriptive statistics the teacher performance variable obtained a minimum score of 207, a maximum score of 299, averaging 244.26, a standard deviation of 13.732. The results of the analysis of mean differences, the empirical mean of teacher performance variables are lower when compared with the hypothetical mean score $(299<360)$. The results of the analysis of the perception of 160 respondents $=39081: 57600=68 \%$. Based on the continuum, the value 39081 is between the moderate to high intervals. Thus, it was concluded that respondents' perceptions of achievement motivation were in the moderate / quite good category.

Furthermore, based on the results of a qualitative analysis of teacher performance variables, it was found that the teacher does not compile a Learning Implementation Plan itself but copy and paste the Learning Implementation plan from other internet sources or colleagues; the teacher copies and paste the Basic Competencies and indicators exactly as contained in the National Regulation of the Minister of Education. The teacher does not understand the preparation of Higher Order Thinking Skill questions and also has not been able to compile an assessment rubric. Learning Implementation Plans prepared by teachers only as a prerequisite for teaching; so it is only to fulfill formal-administrative demands and not be seen in class performance.

This condition is worsened by the strong tendency, the teacher has not been able to escape from the attitude of optimism and pride that they are successful in teaching if what is in the teacher's brain has been successfully pumped to students and students just listen and take notes. Here the creativity and innovation of the teacher has been trapped. This fact 
indicates that all modern learning strategies and models that emphasize student center learning are eliminated by the teacher's reluctance to get out of the safe zone. In that context the learning innovations that teachers follow in training forums, further studies, sharing with colleagues and various professional organizations, are only for information; but not implemented in learning.

ANOVA 1 lane test results difference in teacher perceptions of supervision of school principals obtained values $\mathrm{F}=1,040$ and $\mathrm{P}(\mathrm{P}$-value $)=0.356$. Thus, at the real level $=0.05$ we accept Ho, so the conclusion obtained is that there is no significant difference in the average academic supervision in the three sample groups (elementary, junior high and Senior high school / vocational high school) teachers. There was no significant difference in the mean of academic supervision in the three sample groups (elementary, junior high and senior high school / vocational school teachers), indicating that supervision carried out at elementary, junior high, senior high / vocational school levels, as explained above, was not yet a priority. The principal as a supervisor still considers supervision unimportant. Thus, supervision becomes an activity that is carried out in a haphazard manner, without any program, systematic implementation. Supervision may even be considered as an additional burden for the principal. The success of the principal as a supervisor is influenced by 10 parameters namely 1) supervisor competence; 2) supervision programs are planned together; 3) the use of varied supervision techniques; 4) giving feedback according to the teacher's problem; 5) supervision is carried out in a participatory manner; 6) teacher support and commitment to continue to improve themselves; 7) continuity of guidance and assistance; 8) increasing teacher competency in the learning process; 9) increasing students' absorption ability; 10) continuous supervision evaluation.

ANOVA 1 lane test results, differences in teacher perceptions of teacher achievement motivation, obtained values of $\mathrm{F}=0.043$ and $\mathrm{P}(\mathrm{P}$-value $)=0.958$. Thus, at the real level $=$ 0.05 we accept Ho, so the conclusion obtained is that there is no significant difference in the mean of achievement motivation of teachers in the three sample groups (elementary, junior high and senior high school / vocational high school teachers). There were no significant differences in the mean of achievement motivation of teachers in the three sample groups (elementary, middle and senior high school / vocational school teachers). These results indicate that teachers at elementary, junior high and senior high school / vocational school levels are still difficult to change. They are still canalized in a culture of fatalism which is fertile ground for dictation, a culture of disposition which naturally fosters a culture of silence and kills dynamism, creativity, initiative and commitment to work. In such a situation, the teacher will simply recycle old teaching habits and find it difficult to apply innovation; difficult to breakthrough.

ANOVA 1 lane test results difference in teacher perceptions of teacher performance obtained values $\mathrm{F}=9.765$ and $\mathrm{P}(\mathrm{P}$-value $)=0.958$. Thus, at the real level $=0.05$ we reject Ho, so that the conclusion obtained is that there are significant differences in the mean performance of teachers in the three sample groups (elementary, junior high and senior high school / vocational high school teachers). Considering the results of the test showed that Ho was rejected (there was a difference), a further test (Post Hoc Test) was conducted to see which group was the most dominant. The results of post hoc follow-up tests of boferroni test showed that the ratio of junior high school to senior high school / vocational senior high, mean senior high school / vocational senior high was greater than junior high school (-12.71399*> -.93251); comparison of elementary with senior high school / vocational senior high, mean senior high school / vocational senior high is greater than junior high school $(-11.78148 *>-.93251)$; the ratio of elementary and junior high school means elementary is greater than junior high school (12.71399*> $11.78148 *$ ).

The above findings, Destiyani Gati (2012), found that, 1) the level of achievement motivation of teachers of State Elementary Schools in Pringsurat district was $77 \%$ in the medium category; 2) The level of performance of teachers in Public Elementary Schools in Pringsurat district is $85 \%$ in the high category. 


\section{Conclusion}

a. Results of descriptive analysis of academic supervision variables, obtained a minimum score of 98, a maximum score of 132, averaging 114.11, a standard deviation of 7.520. The results of the analysis of mean differences, mean empirical scores are lower when compared to the hypothetical mean score $(210<270)$. The results of the analysis of the perception of 160 respondents $=28236: 43,200=65 \%$. Based on the continuum line, the value of 39081 is in the moderate / good category. The results of the qualitative analysis showed that the results of the qualitative analysis showed that academic supervision was carried out without a program, the frequency and intensity of academic supervision conducted by the principal was very insufficient. Supervision of principals without using standard instruments and there are no results of the supervision implementation analysis. Supervisors still use the bureaucratic-autocratic approach and are not participatory.

b. Results of descriptive analysis of achievement motivation variables, obtained a minimum score of 207, a maximum score of 299, a mean of 244.26, a standard deviation of 13.732. The results of the analysis of mean differences, the empirical mean of achievement motivation variables are lower when compared to the hypothetical mean score $(299<360)$. The results of the analysis of the perception of 160 respondents $=39081: 57600=68 \%$. Based on the continuum line, the value of 39081 is in the moderate / good category. Result of the qualitative analysis show that teacher achievement motivation is still very dominant due to welfare factors. The teacher has displayed discipline, not delayed work. However, teachers are still dominantly motivated because of welfare; they have not displayed creative, innovative attitudes, independence in work, adaptability and achieving high performance standards.

c. Results of descriptive analysis of teacher performance variables, obtained a minimum score of 207, a maximum score of 299, an average of 244.26, a standard deviation of 13.732. The results of the analysis of mean differences, the empirical mean of teacher performance variables are lower when compared with the hypothetical mean score $(299<360)$. The results of the analysis of the perception of 160 respondents $=39081: 57600=68 \%$. Based on the continuum line, the value of 39081 is in the moderate / quite good category. The results of qualitative analysis of teacher performance variables, it was found that most teachers do not prepare their own learning implementation plans but copy and paste learning implementation plans from internal sources or other colleagues; the teacher copies the basic competency and indicator exactly as it is contained in the regulation of National Education Ministry. The teacher does not understand the preparation of Higher Order Thinking Skill questions and also has not been able to compile assessment rubrics. The learning implementation plans prepared by the teacher are only prerequisites for teaching; so it is only to fulfill formal-administrative demands and not be seen in class performance.

d. ANOVA 1 lane test results of differences in teacher perceptions of supervision of school principals obtained values $\mathrm{F}=1,040$ and $\mathrm{P}(\mathrm{P}$-value $)=0.356$. Thus, at the real level $=0.05$ we accept Ho, so the conclusion obtained is that there is no significant difference in the average academic supervision in the three sample groups (elementary, junior high and senior high school / vocational high school teachers).

e. ANOVA 1 lane test results difference in teacher perceptions of teacher achievement motivation, obtained values of $\mathrm{F}=0.043$ and $\mathrm{P}(\mathrm{P}$-value $)=0.958$. Thus, at the real level $=0.05$ we accept Ho, so the conclusion obtained is that there is no significant difference in the mean of achievement motivation of teachers in the three sample groups (elementary, junior high and senior high school / 
vocational high school teachers). There were no significant differences in the mean of achievement motivation of teachers in the three sample groups (elementary, junior high and senior high school / vocational high school teachers).

f. ANOVA 1 lane test results in differences in teacher perceptions of teacher performance obtained values $\mathrm{F}=9.765$ and $\mathrm{P}(\mathrm{P}$-value $)=0.958$. Thus, at the real level $=0.05$ we reject Ho, so that the conclusion obtained is that there are significant differences in the mean performance of teachers in the three sample groups (elementary, junior high and senior high school / vocational high school teachers). Considering the results of the test showed that Ho was rejected (there was a difference), a further test (Post Hoc Test) was conducted to see which group was the most dominant. The results of post hoc follow-up tests of boferroni test showed that the ratio of junior high to senior high school / vocational high school, mean senior high school / vocational high school was greater than junior high ($12.71399 *>-.93251)$; comparison of elementary with senior high school / vocational high school, mean senior high school / vocational high school is greater than junior high $(-11.78148 *>-.93251)$; the ratio of elementary and junior high means elementary is greater than junior high $(12.71399 *>11.78148 *)$.

\section{REFERENCES}

Aguba, C.R., (2009). Educational administration and management: Issues and perspectives. Enugu: Tons and Tons PDS Publishers.

Anderson, N.H., \& Butzin, C.A. (1974). Performance = Motivation $\mathrm{X}$ Ability: An integration theoretical analysis. Journal of Personality and Social Psychology, 30, 598 - 604

Archibong, F.I., (2013). Instructional supervision in the administration of secondary education: A panacea of quality assurance. European Scientific Journal, 8(13): 1527

Baltacyi-Goktalay et al. (2014). Clinical Supervision Model And Uludag Kdm. International Journal on New Trends in Education and Their Implications. April 2014 Volume: 5 Issue: 2 Article: 01 ISSN 1309-6249. dari :http://www.ijonte.org/FileUpload/ ks63207/File/01a.baltaci-goktalay.pdf. diunduh 12 Maret 2019.Mangkunegara, A. P. (2006). Evaluasi kinerja SDM. Bandung: PT Refika Aditama.

Bernard, J.M. and R.K. Goodyear, 2009. Fundamentals of clinical supervision. 4th Edn., Massachusetts: Allyn \& Bacon

Blasé, J., Blasé, J. \& Phillips, D.Y. (2010). Handbook of school improvement: How highperforming principals create high-performing schools. Thousand Oaks, CA: Corwin Press

Bailey, K. M., Curtis, A., \& Nunan, D. (2001). Pursuing professional development: The self as a source. Boston: Heinle \& Heinle

Bessong, F. E., \& Ojong, F. (2009). Supervision as an instrument of teaching-learning effectiveness: Challenge for the Nigerian practice. Global Journal of Educational Research, 8 ( $1 \& 2), 15-20$. 
Broussard, S. C., \& Garrison, M. E. B. (2004). The relationship between classroom motivation and academic achievement in elementary school-aged children. Family and ConsumerSciences Research Journal, 33(2), 106-120.

Burant, S. E. (2009). The relationship of instructional supervision and professional learning communities as catalysts for authentic professional growth: A study of one school division (Master's Thesis, University of Saskatchewan). [Online] http://www.library2.usask.ca/theses/available/etd09202009165813/unrestricted/B ura nt_Thesis_FINAL_August_2009.pdf . Retrieved on 14th November 2019.

Degeng, I.N.S. 1991. Karakteristik Belajar Mahasiswa Berbagai Perguruan Tinggi di Indonesia. Jakarta PAU-UT Dirjend Dikti Depdikbud

Destiyani, Gati (2012). Pengaruh Motivasi Berprestasi Guru Terhadap Kinerja Guru Sekolah Dasar Negeri di Kecamatan Pringsurat Kabupaten Temanggung. S1 thesis, Universitas Negeri Yogyakarta

Glathorne, A.A., (2000). The principal as curriculum leader: Shaping what is taught and tested. Thousand Oaks, California: Corwin

Glickman, C.D., (2002). Supervision of instruction: A developmental approach. Boston: Allan and Bacon. Glickman, C.D., S.P. Gordon and J.M.

Glickman, C.D., S.P. Gordon and J.M. Ross-Gordon, (2009). Super vision and instructional leadership: A developmental approach. 7th Edn., New York: Pearson Education Inc

Hismanoglu, M., \& Hismanoglu, S. (2010). English language teachers' perceptions of educational supervision in relation to their professional development: A case study of northern Cyprus. Novitas-ROYALS (Research on Youth and Language), 4 (1), 16-34.

Hersey, P. and Blanchard, K.H. (1988). Management of Organizational behavior:Utilizing human resources (5th ed). Englewood Cliffs, NJ: Prentice-Hall.

Ivancevich et.al. (1997) Organizational Behavior and Performance, Santa Monica California.

James Ang Jit \& Balasandran Ramiah. (2012). Kepimpinan pengajaran, satu panduan praktikal. Kuala Lumpur: PTS Publications and Distributor.

Krishnan, V. R. (2003), 'Do Business Schools Change Students' Values Along Desirable Lines? (A Longitudinal Study) in Business Education and Training: A Value-laden Process, S. M. Natale \& A. F. Libertella, University Press of America, Lanham, Maryland, and Oxford University Center for the Study of Values in Education and Business, vol.8 (Immortal Longings), pp. 26-39.

Kramar, R.,P. Mcgraw dan R. Schuler, (1997). Human Resource Management in Australia. South Melbourne: Addison Wesley Longman Australia Pty.Limited.

Kweku Esia-Donkoh and Eric Ofosu-Dwamena (2014). EFFECTS OF EDUCATIONAL SUPERVISION ON PROFESSIONAL DEVELOPMENT: PERCEPTION OF PUBLIC BASIC SCHOOL TEACHERS AT WINNEBA, GHANA. British Journal of Education Vol.2, No.6, pp.63-82, December 2014.

McClelland, D.C. (1975). The Achievement Motivation. New York: Irvington. 
Meor Ibrahim Kamaruddin \& Norziana Anuar. (2008). Tinjauan terhadap tahap penyeliaan guru pembimbing terhadap guru pelatih semasa menjalani latihan mengajar. Jurnal Pendidikan. Fakulti Pendidikan. Skudai : Universiti Teknologi Malaysia.

Mangkunegara (2006). Perencanaan dan. Pengembangan Manajemen Sumber Daya Manusia, Pen. PT Refika

Mardhiah, J., \& Rabiatul Adawiyah, A.R. (2016).Hubungan kualiti penyeliaan pengajaran dengan efikasi kendiri guru. Working paper, Universiti Sains Malaysia.

Mohammed Sani. (2013). Peranan guru kanan mata pelajaran dalam mempertingkatkan kualiti pengajaran guru-guru. Jurnal Kurikulum dan Pengajaran Asia Pasifik 1(1), 28- 41 .

Noosheen Nawaz and Hina Yasin (2018). Determinants of Motivation in Teachers: A Study of Private Secondary Schools Chain Networks in Bahawalpur Journal of Education and Practice www.iiste.org ISSN 2222-1735 (Paper) ISSN 2222-288X (Online) Vol.6, No.4, 2015

Nbina, J. B. (2010). Re-visiting Secondary School Science Teachers Motivation Strategies to Face the Challenges in the 21st Century. New York Science Journal.

Okendu, J.N.(2012).The influence of instructional process and supervision on academic performance of secondary school students of Rivers State, Nigeria. Academic Research international journal 3(1): pp.147-151.

Rahabav, Patris (2016). The Effectiveness of Academic Supervision for Teachers. Journal of Education and Practice www.iiste.org ISSN 2222-1735 (Paper) ISSN 2222288X (Online) Vol.7, No.9, 2016.

Rahabav, Patris (2014). Kepemimpinan Kepala Sekolah di Era Otonomi Pendidikan. Yigyakarta: Kanisius.

Rahabav, Patris (2012). Pengaruh Kepemimpinan terhadap Kinerja Layanan Perizinan di Kota Ambon. Tesis.UNM: Makasar

Rozalina, Khalid.; Mohd Sofian Omar Fauzee.; Yaakob Daud, Puteri Darishah Dali \& Hareesol Khun-inkeeree (2019). Effects of Teaching and Learning Supervision on Teachers Attitudes to Supervision at Secondary School in Kubang Pasu District, Kedah. International Journal of Instruction, 12(1), 1335-1350. https://doi.org/10.29333/iji.2019.12185a. International Journal of Instruction January $2019 \bullet$ Vol.12, No.1 e-ISSN: 1308-1470 • www.e-iji.net p-ISSN: 1694609X pp. 1335-1350 Citation: Khun-inkeeree, H., Dali, P. D., Daud, Y., Fauzee, M. S. O., \& Khalid, R.

Shukri Zain. (2011). Penyeliaan pendidikan: Teori dan amalan. Emeritus Publications, Tanjong Malim.

Sergiovanni, T.J. and R. Starratt, (2007). Supervision: A redefinition. 9th Edn., New York: MacGraw-Hill.

Segun, O. (2004). Educational supervision: Perspective and practice in Nigeria. Ile Ife: University of Ile Ife.

Sergiovanni, T.J., (2009). The principalship: A reflective practice perspective. Boston: Pearson Educational Inc. 
Smylie, M.A. (2010). Continuous school improvement. Thousand Oaks, CA: Corwin Press.

Singh, Kulwinder (2011) Study of Achievement Motivation in Relation to Academic Achievement of Students. International Journal of EducationG2al Planning \& Administration. ISSN 2249-3093 Volume 1, Number 2 (2011), pp. 161-171

Wan Shafira Wan Zaki. (2011). Aplikasi gaya penyeliaan pengajaran guru pembimbing dalam pengurusan latihan mengajar. Tesis Sarjana yang tidak diterbitkan. Fakulti Pendidikan. Skudai: Universiti Teknologi Malaysia.

Winardi, J. (2001). Motivasi dan Pemotivasian dalam Manajemen. Jakarta: Rajawali

Vijayaamalar, G., \& Suhaida, A. K. (2013). Sikap guru terhadap penyeliaan pengajaran yang dijalankan di sekolah menengah kebangsaan, zon Bangsar, Kuala Lumpur. Paper presented at the School of Education, University Putra Malaysia (GREDUC).

Tesfaw, T. A. \& Hofman, R. H. (2012). Instructional supervision and its relationship with professional development: Perception of private and government secondary school teachers in Addis Ababa. [Online]. Retrieved on 14th November 2019 from http://www.eric.ed.gov/PDFS/ED534226.pdf. 